\title{
Root-knot nematode, Meloidogyne javanica, in response to soil fertilization
}

\author{
S. Hemmati ${ }^{a}$ and A. Saeedizadeh ${ }^{b *}$ \\ ${ }^{\mathrm{a} O f f i c e}$ of Education, Semnan, Iran

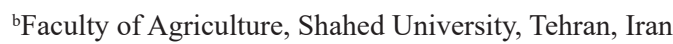 \\ *e-mail: ayatsaeed314@gmail.com
}

Received: December 31, 2018 - Accepted: April 29, 2019 - Distributed: August 31, 2020

(With 9 figures)

\begin{abstract}
Root-knot nematodes (RKNs) (Meloidogyne spp.) are well known disease problem causing major losses in vegetable crops. Although, chemical nematicides have been used as one of the primary means for controlling RKNs, reliance on these nematicides is associated with heavy costs and negative effects on human health and environment. In this research, the suppressing potential of 6 Iranian commercial fertilizers on RKNs was investigated in laboratory and greenhouse conditions as an alternative to reduce the use of chemical nematicides. For this purpose, M. javanica inoculum was thoroughly mixed with autoclaved sandy loam soil. Then, 6 fertilizers (biofertilizer, phosphate chemical fertilizer (phosphate), potassium chemical fertilizer (potassium), peat moss, vermicompost, and leaf mold) were added individually to the inoculated soil, according to the defined treatments. The nematicide Cadusafos was used as a positive control. A negative control was also included in the experiment (including no fertilizer and no nematicide). Four-leaf seedlings of the tomato (Super Chief cv.) were transferred to the pots filled using $2 \mathrm{~kg}$ of the treated soil. After 60 days, reproduction factor (RF), egg mass, and root galling of the nematode were recorded. The results showed that, fertilizer-treated soils had significantly $(\mathrm{P} \leq 0.05)$ lower root galling, egg mass, and $\mathrm{RF}$ compared to the negative control. After the nematicide treatment, the highest suppression capability on the RKN was obtained in treatments of phosphate, biofertilizer, potassium, vermicompost, peat moss, and leaf mold, respectively. It can be concluded that, replacing chemical nematicides with fertilizers may be considered as a successful nematode management in tomato fields.
\end{abstract}

Keywords: nematode, nematicidal effect, eco-friendly control, gall.

\section{Nematoide-das-galhas, Meloidogyne javanica, em resposta à fertilização do solo}

\section{Resumo}

Nematoides-das-galhas das raízes (RKNs) Meloidogyne spp. causam perdas consideráveis na produção de hortaliças em todo o mundo. Embora o uso de nematicidas químicos seja um dos principais meios de controle de RKNs, a dependência nesses nematicidas está associada aos altos custos e impactos negativos à saúde humana e ao meio ambiente. No presente estudo, foi investigado o potencial de supressão de seis fertilizantes comerciais iranianos em RKNs em condições de laboratório e estufa, a fim de reduzir o uso de nematicidas químicos. Para este propósito, o inóculo de M. javanica foi totalmente misturado com o solo franco-arenoso autoclavado. Em seguida, os fertilizantes (biofertilizante, fertilizante químico de fosfato (fosfato), fertilizante químico de potássico (potássio), musgo de turfa, vermicompostagem e bolor) foram adicionados e misturados individualmente ao solo inoculado, de acordo com os tratamentos definidos. O nematicida Cadusafós foi utilizado como controle positivo. Um controle negativo também foi considerado (sem fertilizante e sem nematicida). Mudas de quatro folhas do tomate (Super Chief cv.) foram transferidas para vasos cheios de $2 \mathrm{~kg}$ de solo tratado. Após 60 dias, o fator de reprodução (FR), a massa de ovos e o número de galhas foram registrados. Os resultados mostraram que os tratamentos com fertilizantes apresentaram significativamente $(\mathrm{P} \leq 0,05)$ menor número de galhas nas raízes, massa de ovos e $\mathrm{FR}$, em comparação com o controle negativo. Depois do controle positivo, a maior capacidade de supressão de $M$. javanica foi obtida nos tratamentos com fosfato, biofertilizante, potássio, vermicompostagem, turfa e bolor, respectivamente. Conclui-se que a substituição de nematicidas químicos por fertilizantes pode ser uma estratégia aceitável para se alcançar uma gestão bem-sucedida de nematoides em campos de tomate.

Palavras-chave: nematoide, efeito nematicida, controle ecológico, galha. 


\section{Introduction}

Root-knot nematodes (RKNs), (Meloidogyne spp.) are important pathogens causing yield loss in greenhouses and fields (Perry et al., 2009). In Iran, M. javanica (Treub) Chitwood has been found as a major problem in tomato (Solanum lycopersicum L.) cultivation (Gharabadiyan et al., 2013). Conventionally, Iranian farmers have used chemical methods to control nematodes. Apart from high costs, the application of nematicides is often associated with harmful environmental side effects restricting the achievement of integrated nematode management. Thus, the use of non-chemical management strategies is recommended to avoid such disadvantages (Gowen, 1997).

Eco-friendly management practices of plant parasitic nematodes (PPNs) have been considered in previous studies (Padgham and Sikora, 2007). Some studies suggested that PPNs may be influenced by soil fertilization (Ahmadi Mansourabad et al., 2016; Melo Santana-Gomes et al., 2013; Khan et al., 2012). Soil fertilization increases the growth and development of plants, as well as improving the performance of agricultural products. Environmental concerns regarding the synthetic nematicides and their high costs raise the suppressive effect of fertilizers on PPNs in soil environment as a viable solution. In addition to increasing plant growth and development, this strategy can be coupled with PPNs populations decline and their damage. Although, the plant response to the pathogens is genetically controlled, but this phenomenon is significantly influenced by environmental and nutritional parameters. Fertilizers increase the level of plant resistance or tolerance to pathogens and pests by increasing plant access to the nutrients. Therefore, stronger plants have more capacity to compensate for the loss of photosynthesis or to reduce the root and leaf area caused by damage to pests and pathogens, including PPNs (Melo Santana-Gomes et al., 2013; Khan et al., 2012). Researches have shown that phosphate fertilizer has a suppressive potential on RKNs (Al-Banna et al., 2007; Bado et al., 2011; Hu and Qi, 2010). Also, soil organic amendments were reported to have similar reducing effects on PPNs (Sultana et al., 2011). Moreover, vermicomposting materials were found to have a nematistatic effect on PPNs populations (Edwards et al., 2007; Pathma and Sakthivel, 2012).

Considering the benefits of fertilizers on crop plants, study of their controlling effect on PPNs would be useful for reduction of nematicides application and achievement of sustainable agriculture. Therefore, the main objective of this study was investigating the use of fertilizers as a management method against $M$. javanica. In the "in vitro" assays, the effect of fertilizers was evaluated on the mortality of second stage juveniles $\left(\mathrm{J}_{2} \mathrm{~s}\right)$ and egg hatching of $M$. javanica in Petri dish. The pathogenicity and reproduction of the nematode were studied on roots of host plants treated with the fertilizers in the "in vivo" assay. As a secondary objective, the plant response (growth parameters of the plant) to fertilizers was evaluated in the absence of nematodes.

\section{Material and Methods}

\subsection{M. javanica inoculum preparation}

M. javanica inoculum was prepared according to the single egg mass method (Hussey and Barker, 1973). For this purpose, first nematode-galled roots of the tomato (Super Chief cv.) were collected from the fields in Karaj, Iran. Species identification was performed based on female body characteristics, especially the perineal pattern (Cetintas and Cakmak, 2016). Subsequently, in order to propagate the nematode, the egg masses separated from galled roots were added to the pots filled with steam-sterilized sandy soil containing the tomato seedlings (Super Chief cv.). Then, the pots were kept at a greenhouse (temperature: $25 \pm 2{ }^{\circ} \mathrm{C}$; day length: 10 hours). After two months, the roots with galls were harvested, rinsed, chopped, and then they were disinfected by $1 \% \mathrm{NaOCl}$ solution. The derived suspension was then incubated in distilled water at $25 \pm 2{ }^{\circ} \mathrm{C}$ for a week. Finally, the eggs and emerged $\mathrm{J}_{2} \mathrm{~s}$ were collected, counted, and considered as the nematode inoculum or population under test for in vitro assays and pot experiment (Saeedizadeh, 2016).

\subsection{Soil, host plant and fertilizers}

A quantity $(\approx 300 \mathrm{~kg}$ ) of soil was collected from several locations in a field of the tomato (Super Chief cv.) in Karaj, Iran. The soil (consisting of sand: $85 \%$, silt: $11 \%$, clay: $4 \%$, organic matter: $0.3 \%$, and $\mathrm{pH}: 7.2$ ) was thoroughly mixed, and then was sieved using a screen (with $5 \mathrm{~mm}$ opening diameter). The soil was autoclaved, and was used as a sterile soil in the pot experiment. Four-leaf seedlings of tomato (Super Chief cv.), previously grown in a sterile sandy substrate, were considered as host plants. 6 commercial fertilizers were used including a biofertilizer (Nitroxin ${ }^{\circledR}$, Granule 10\%, Mehr Asia Co., Inc., containing Azotobacter chroococcum, A. salinestris, and A. vinelandii); and phosphate chemical fertilizer $\left(\mathrm{P}_{2} \mathrm{O}_{5}\right)$, potassium chemical fertilizer $\left(\mathrm{K}_{2} \mathrm{O}\right)$, peat moss, vermicompost, and leaf mold, purchased from Gilda and Guilan Zuk Companies of Iran. Cadusafos (Rugby ${ }^{\circledR}$ Granule 10\%) was used as a reference nematicide (as a positive control).

\subsection{Petri dish assays}

\subsubsection{The effect of the fertilizers on egg hatching of M. javanica}

In order to determine the effect of the fertilizers on egg hatching rate (\%) of $M$. javanica, an in vitro assay was arranged in Petri dish conditions. The assay was conducted using eggs suspension as a population under test. The density of the eggs suspension was estimated by an inverted microscope (40x). The suspension was transferred to the plastic petri dishes $(5 \mathrm{~cm}$ diameter $)$ with 200 eggs as a replicate. The eggs were exposed to the fertilizers at 5 doses of $1,2,4,8$, and $16 \mathrm{~g}^{1^{-1}}$ distilled water, and the nematicide, Cadusafos at 5 doses of $0.5,1$, $1.5,2$, and $2.5 \mathrm{~g} \mathrm{l}^{-1}$ distilled water at $25 \pm 2{ }^{\circ} \mathrm{C}$, with $80 \%$ of relative humidity and without exposure to the light for 8 days. Eggs in distilled water (containing no fertilizer 
and no nematicide) were considered as a negative control. Egg hatching rate (\%) was determined based on the number of hatched eggs using an inverted microscope (40x) on the second, fourth, sixth, and eighth days after starting the assay. Each treatment had 4 replicates (Petri dishes). After eighth day, in order to check the recovery of remaining eggs, the eggs were transferred in fresh water and were incubated in order to ensure the nematicidal or nematistatic effect of the fertilizers (Habash and Al-Banna, 2011).

\subsubsection{The effect of the fertilizers on $\mathrm{J}_{2} \mathrm{~s}$ mortality of M. javanica}

In order to evaluate the effect of the fertilizers on $\mathrm{J}_{2} \mathrm{~s}$ mortality rate $(\%)$ of $M$. javanica, an assay was arranged using eggs suspension. The suspension was incubated at $25 \pm 2{ }^{\circ} \mathrm{C}$ for a week. Then, the emerged $\mathrm{J}_{2} \mathrm{~s}$ were collected and counted as a population under test. $\mathrm{J}_{2} \mathrm{~s}$ population was set to $200 \mathrm{~J}_{2} \mathrm{~s}$ per plastic Petri dish (with $5 \mathrm{~cm}$ diameter). The $\mathrm{J}_{2} \mathrm{~s}$ were exposed to the fertilizers at 5 doses of $1,2,4,8$, and $16 \mathrm{~g} \mathrm{l}^{-1}$ distilled water, and the nematicide, Cadusafos at 5 doses of $0.5,1,1.5,2$, and $2.5 \mathrm{~g}^{-1}$ distilled water at $25 \pm 2{ }^{\circ} \mathrm{C}$, with $80 \%$ of relative humidity and without exposure to the light for 4 days. A negative control was also considered (containing no fertilizer and no nematicide). The number of dead $\mathrm{J}_{2} \mathrm{~s}$ was determined every day using stereomicroscope (40x), and then the $\mathrm{J}_{2} \mathrm{~s}$ mortality rate $(\%)$ was estimated. $\mathrm{J}_{2} \mathrm{~s}$ population in distilled water was taken as a positive control. Each treatment had 4 replicates (Petri dishes) (Habash and Al-Banna, 2011).

\subsection{Pot assays}

\subsubsection{The effect of the fertilizers on pathogenicity of M. javanica}

A pot assay was arranged to study the pathogenicity and reproduction of $M$. javanica on the roots of the host plant. The nematode inoculum ( $10 \mathrm{~J}_{2} \mathrm{~s} \mathrm{~g}^{-1}$ soil) was added to the sterile soil and was thoroughly mixed. The inoculated soil was divided into 36 parts or treatments ( 7 amendments [ 6 fertilizers plus 1 nematicide $] \times 5$ doses; plus, a negative control [containing no fertilizer and no nematicide]) $8 \mathrm{~kg}$ (4 replicates or pots $\times 2 \mathrm{~kg}$ soil). Then, the soil was treated with the fertilizers at 5 doses of 1, 2, 4, 8, and $16 \mathrm{~g} \mathrm{~kg}^{-1}$ soil (Ploeg, 2008); also, the nematicide, Cadusafos was used as a positive control at 5 doses of $0.5,1,1.5,2$, and $2.5 \mathrm{~g} \mathrm{~kg}^{-1}$ soil (Safdar et al., 2012). Finally, a four-leaf seedling of the host plant (tomato cv. Super Chief) was transferred to each pot filled with $2 \mathrm{~kg}$ of the treated soils. The pots were kept at greenhouse conditions (temperature: $25 \pm 2{ }^{\circ} \mathrm{C}$; lighting period: 12 hours a day) for 2 months. The plants were sufficiently irrigated, $(\approx 100 \mathrm{~mL}$ daily $)$.

\subsubsection{Studied traits of $M$. javanica}

The number of egg masses and galls per root, and RF were counted and calculated as indicators of reproduction and pathogenicity of M. javanica (Hussey and Janssen, 2002; Soheili and Saeedizadeh, 2017; Tabatabaei and Saeedizadeh, 2017). For this purpose, after the growth period in the greenhouse, galled roots were harvested; then, the soil was gently removed from the roots using tap water. The galls were counted and, the roots were crushed into pieces of 2-3 cm and were exposed to Floxin B $\left(0.15 \mathrm{~g} \mathrm{l}^{-1}\right)$ solution in order to determine the number of egg mass. Thereafter, highlighted egg masses were counted using a stereomicroscope (20x) (Hussey and Janssen, 2002). Soil of treatments was also sampled to analyze the nematode population.

In order to estimate the final population of nematodes per pot, a subsample (100 g) of available soil for each pot was processed for nematode extraction according to the centrifugation or sugar flotation method (Jenkins, 1964). The nematodes were collected and counted at 40x magnifications, and finally, the nematodes population was estimated in $2 \mathrm{~kg}$ soil (per pot). In order to determine the nematode population within galled roots, a subsample ( $5 \mathrm{~g}$ ) of well-mixed chopped roots was suspended in water, and then nematodes were counted at 40x magnification. Hence, the number of nematodes was estimated in the total weight of the root (Coolen and D'Herde, 1972). According to the study by Maleita et al. (2012), RF was calculated as follows: $\mathrm{RF}=(\mathrm{Pf}-\mathrm{Pi}) \mathrm{Pi}^{-1}$. In this equation, $\mathrm{Pf}$ is final population (number of eggs and juveniles within roots, and $\mathrm{J}_{2} \mathrm{~s}$ in soil) and $\mathrm{Pi}$ is primary population (the nematode inoculum).

\subsubsection{The effect of the fertilizers on host plants growth properties}

The fertilizers effect on tomato seedling growth properties was evaluated in a test under similar conditions to the first pot assay without the nematode inoculum. In this test, after soil treatment with the amendments (according to the doses) and transferring to the pots, 3 seeds of tomato were sowed in each pot. After germination, the seedlings were thinned, so that only a seedling remained in each pot. The pots were kept in the greenhouse; and the plants were irrigated as needed. The pot containing one plant was represented a replicate. 2 months after sowing seeds, plants were taken, and rewetted. Then, their fresh root and shoot was weighed, and length of stem was measured, as host plants growth properties (Soheili and Saeedizadeh, 2017).

\subsection{Statistical analysis}

All assays were conducted as a factorial with 7 amendments ( 6 fertilizers and 1 nematicide) at 5 levels of dose, based on a Completely Randomized Design (CRD) with 4 replications. Petri dish assays were conducted at 5 doses of $1,2,4,8$, and $16 \mathrm{~g} \mathrm{l}^{-1}$ distilled water (for the fertilizers), and at doses of $0.5,1,1.5,2$, and $2.5 \mathrm{~g} \mathrm{l}^{-1}$ distilled water (for the nematicide). The egg hatching was assayed during the intervals of 2, 4, 6 and 8 days, and the $\mathrm{J}_{2} \mathrm{~s}$ mortality was studied during the intervals of $1,2,3$, and 4 days. Pot assay was carried out to evaluate the fertilizers and the nematicide effect on the nematode pathogenicity of the tomato seedling at doses of $0.5,1,1.5,2$ and $2.5 \mathrm{~g} \mathrm{~kg}^{-1}$ soil (for the nematicide) and at dosses of 1, 2, 4, 8, and $16 \mathrm{~g} \mathrm{~kg}^{-1}$ soil (for the fertilizers). These conditions were 
also considered to study the plant growth properties in the second pot assay, containing no nematode inoculum. Data were subjected to ANOVA using SAS software version 9.1. Cluster analysis was done using Minitab software version 16.3.2, based on Complete Linkage method and Euclidean Similarity Matrix. Diagrams were drawn using Microsoft Excel software 2013. Mean comparisons were done using Duncan's test.

\section{Results}

\subsection{Petri dish assays}

The most suppressive effect of fertilizers on egg hatching was achieved by phosphate, vermicompost, biofertilizer, potassium, peat moss, and leaf mold treatments, respectively. At the same exposure times, the egg hatching rate decreased by increasing the dosage of fertilizers
(Figures 1 and 2). The highest to the lowest rate (\%) of $\mathrm{J}_{2} \mathrm{~s}$ mortality was observed in phosphate, biofertilizer, vermicompost, potassium, peat moss, and leaf mold treatments, respectively. The mortality rate increased as a result of increasing the dose and exposure time. At the end of the first day, $100 \%$ of $\mathrm{J}_{2} \mathrm{~s}$ mortality was found in all treatments and at the dose of $16 \mathrm{~g} \mathrm{~kg}^{-1}$ soil, except in cases of leaf mold and peat moss treatments. Full mortality rate $(100 \%)$ occurred in all treatments on the fourth day at all doses, except in the case of leaf mold treatment (Figures 3 and 4).

\subsection{Pot assays}

Amending the soil by fertilizers led to the decreased activity (number of galls and egg masses, and RF) of M. javanica in the rhizosphere and on the roots of tomato seedlings (Figures 5 and 6). However, the fertilizers
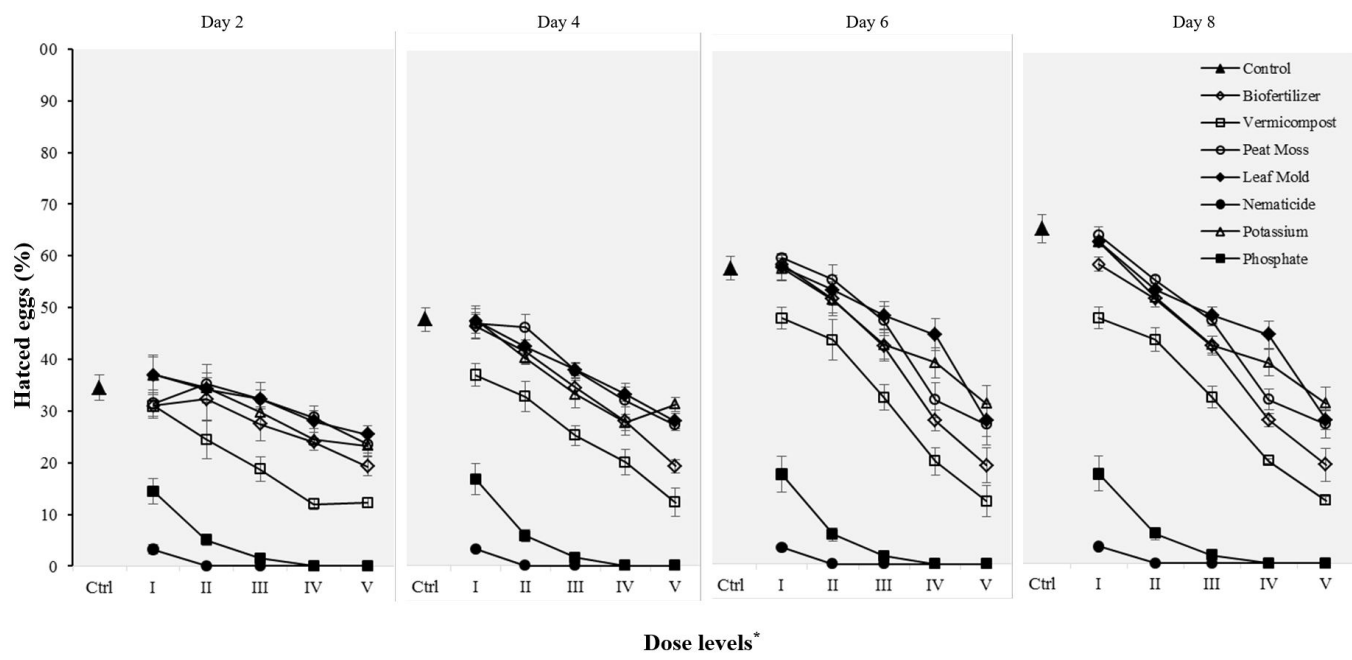

Figure 1. Effect of amendments (biofertilizer, peat moss, leaf mold, potassium, phosphate, vermicompost and nematicide) and their dose levels on egg hatching of Meloidogyne javanica at exposure times. *Defined doses at the X axis (I, II, III, IV and V) respectively correspond to $1,2,4,8$ and $16 \mathrm{~g}^{-1}$ soil for the fertilizers; and $0.5,1,1.5,2$ and $2.5 \mathrm{~g} \mathrm{l}^{-1}$ soil for the nematicide (Cadusafos).

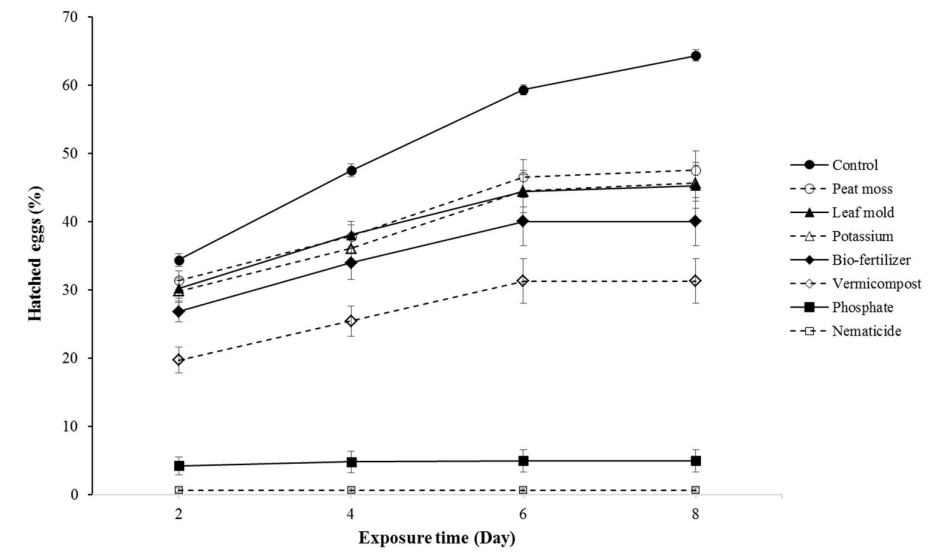

Figure 2. Effect of amendments (biofertilizer, peat moss, leaf mold, potassium, phosphate, vermicompost and nematicide) on egg hatching of Meloidogyne javanica at exposure times. 

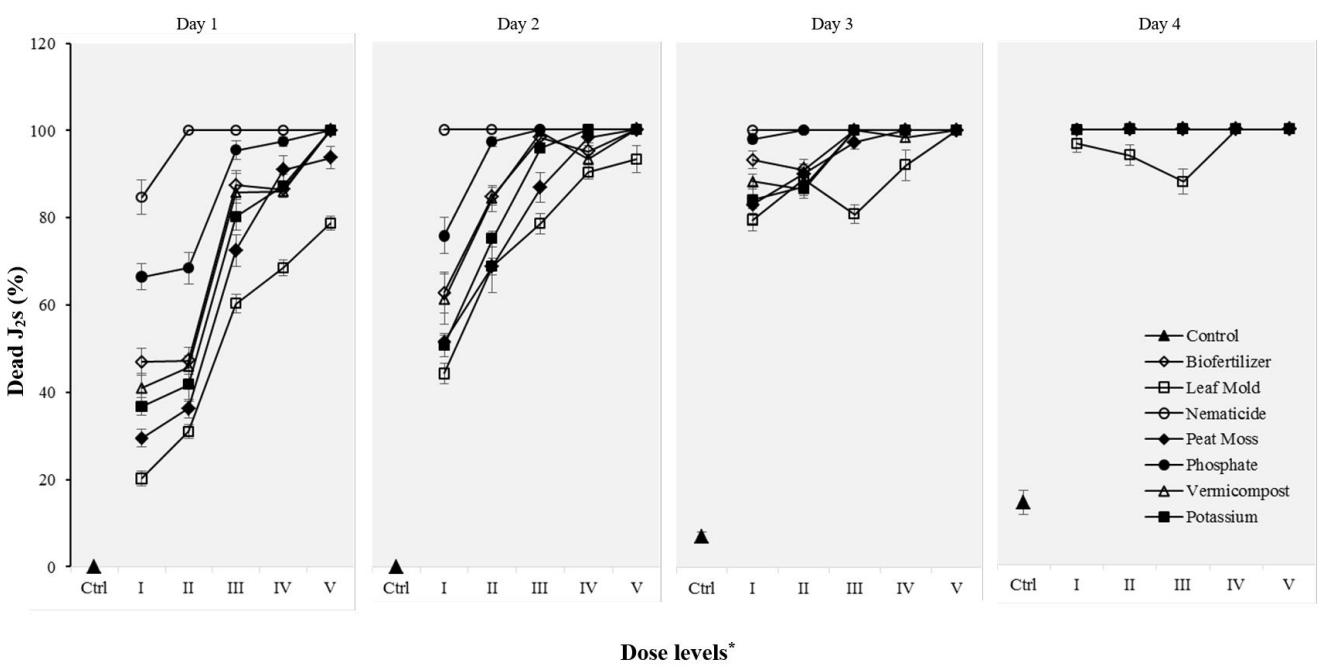

Figure 3. Effect of amendments (biofertilizer, peat moss, leaf mold, potassium, phosphate, vermicompost and nematicide) and their dose levels on $\mathrm{J}_{2} \mathrm{~s}$ mortality of Meloidogyne javanica at exposure times. *Defined doses at the X axis (I, II, III, IV and V) respectively correspond to $1,2,4,8$ and $16 \mathrm{~g} \mathrm{l}^{-1}$ soil for the fertilizers; and $0.5,1,1.5,2$ and $2.5 \mathrm{~g} \mathrm{l}^{-1}$ soil for the nematicide (Cadusafos).

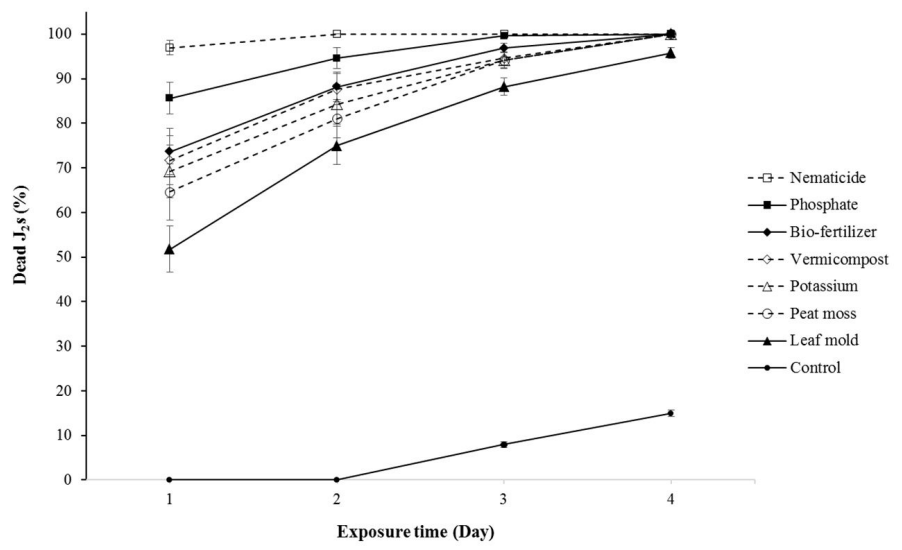

Figure 4. Effect of amendments (biofertilizer, peat moss, leaf mold, potassium, phosphate, vermicompost and nematicide) on $\mathrm{J}_{2} \mathrm{~s}$ mortality of Meloidogyne javanica at exposure times.
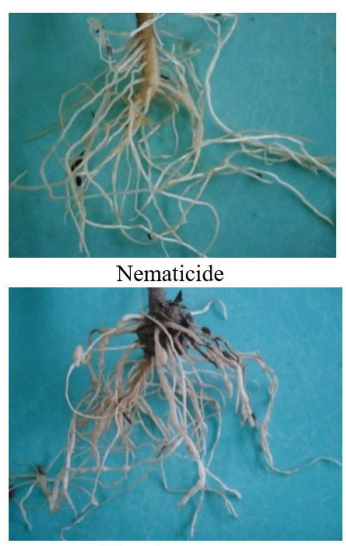

Vermicompost

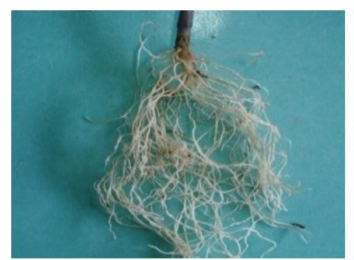

Phosphate

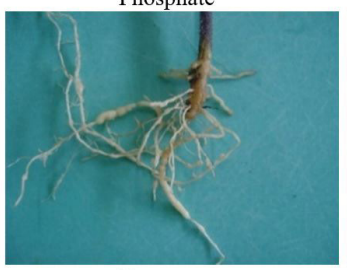

Peat moss

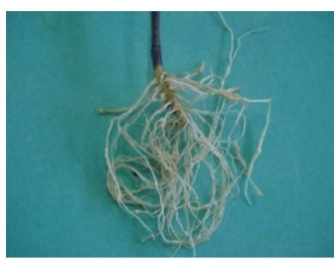

Bio-fertilizer

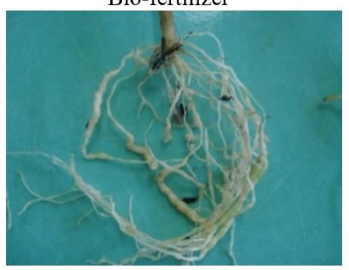

Leaf mold

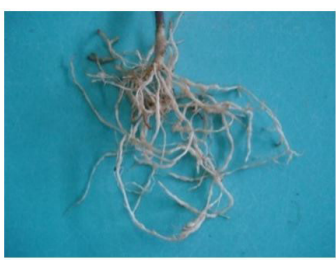

Potassium

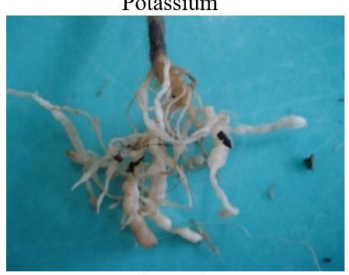

Control

Figure 5. Effects of amending the soil on the symptoms (galled root) of root-knot nematode, Meloidogyne javanica on the root of tomato seedlings. 


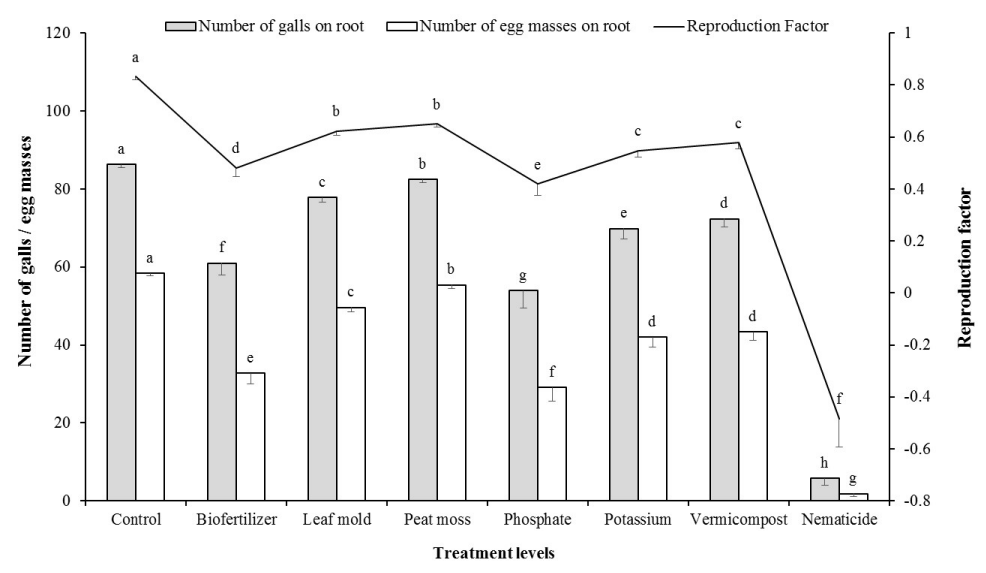

Figure 6. Effects of treatments of soil amendments on the number of galls, egg masses, and reproduction factor of Meloidogyne javanica on the root of tomato two months after inoculation.

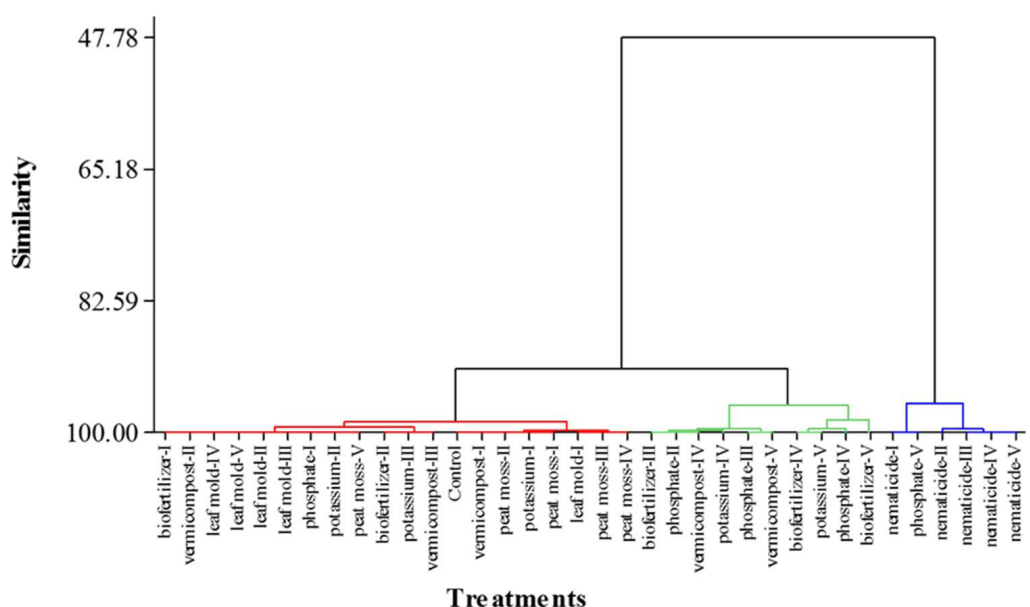

Figure 7. Cluster analysis of the effects of the studied treatments on activity (galling and reproduction) of Meloidogyne javanica in tomato seedling rhizosphere. Defined doses at the $\mathrm{X}$ axis (I, II, III, IV and V) respectively correspond to $1,2,4,8$ and $16 \mathrm{~g} \mathrm{~kg}^{-1}$ soil for the fertilizers; and $0.5,1,1.5,2$ and $2.5 \mathrm{~g} \mathrm{~kg}^{-1}$ soil for the nematicide (Cadusafos).

could not reset galling, egg mass, and RF; similar to the positive control (nematicide). This reduction occurred in all fertilizer treatments, especially phosphate, biofertilizer, and potassium, while a minimum level of control effect on nematode activity was obtained in leaf mold, peat moss, and vermicompost, respectively. Increasing the amendment (fertilizer or nematicide) dose caused further reduction in galling, egg masses, and RF (Figure 6).

Cluster analysis grouped the treatments into 3 distinct clusters based on Complete Linkage method and Euclidean Similarity Matrix (Figure 7 and Table 1). The cross-validation results confirmed that, the treatment grouping was done correctly, and the assignment of treatments to corresponding groups was accurate (Data not shown). Among attained clusters, cluster III with 6 members comprising of phosphate (16 $\left.\mathrm{g} \mathrm{kg}^{-1} \mathrm{soil}\right)$, nematicide $\left(0.5 \mathrm{~g} \mathrm{~kg}^{-1} \mathrm{soil}\right)$, nematicide (1 $\mathrm{g} \mathrm{kg}^{-1}$ soil), nematicide (1.5 $\mathrm{g} \mathrm{kg}^{-1}$ soil), nematicide ( $2 \mathrm{~g} \mathrm{~kg}^{-1}$ soil), and nematicide ( $2.5 \mathrm{~g} \mathrm{~kg}^{-1}$ soil) had the lowest number of galls, egg masses, and RF (Table 1).

In order to find the best control treatment, the members of cluster III were compared based on mean traits related to nematode activity. The results showed that, the best control of nematode population was achieved by nematicide (all doses) and phosphate treatment (16 $\mathrm{g} \mathrm{kg}^{-1}$ soil). Moreover, the suppressive effect of phosphate- $\mathrm{V}$ was almost equal to that of nematicide $\left(0.5 \mathrm{~g} \mathrm{~kg}^{-1}\right.$ soil $)$. Among the fertilizers, the highest suppressive effect on galling was observed at the highest dose (16 $\mathrm{g} \mathrm{kg}^{-1}$ soil) of phosphate, while non-galling occurred at doses of $1.5,2$, and $2.5 \mathrm{~g} \mathrm{~kg}^{-1}$ soil of Cadusafos. In the nematicide treatment, the final nematodes population was zero $(\mathrm{RF}=-1)$ at doses of 2 and $2.5 \mathrm{~g} \mathrm{~kg}^{-1}$ soil (i.e. the rhizosphere and roots were free of nematodes). However, in case of treatment with 
Table 1. Properties of clusters obtained on the basis of data recorded for number of gall (NG), number of egg mass (NEM) and Reproduction factor (RF) of Meloidogyne javanica in the rhizosphere of tomato seedlings in a greenhouse.

\begin{tabular}{crccc}
\hline Cluster & \multicolumn{1}{c}{ NG } & NEM & RF & N \\
\hline 1 & $78.9 \pm 1.17 \mathrm{a}$ & $50.92 \pm 1.21 \mathrm{a}$ & $0.65 \pm 0.02 \mathrm{a}$ & 20 \\
2 & $57.38 \pm 2.78 \mathrm{~b}$ & $29.43 \pm 2.5 \mathrm{~b}$ & $0.43 \pm 0.03 \mathrm{~b}$ & 10 \\
3 & $8.38 \pm 4.21 \mathrm{c}$ & $2.63 \pm 1.53 \mathrm{c}$ & $-0.39 \pm 0.21 \mathrm{c}$ & 6 \\
\hline
\end{tabular}

Cluster analysis has been carried out using complete linkage method and Euclidean similarity matrix. N refers to number of treatments in each class.

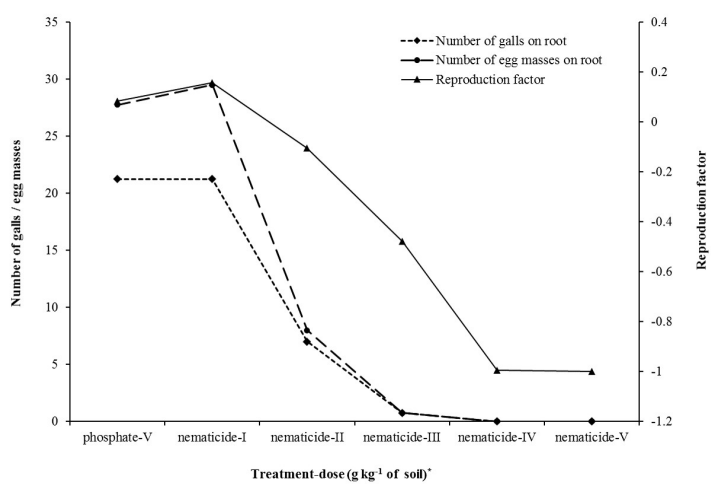

Figure 8. Mean number of galls and egg masses, and reproduction factor of Meloidogyne javanica on the roots of tomato. *Defined doses at the X axis (I, II, III, IV and V) respectively correspond to $1,2,4,8$ and $16 \mathrm{~g} \mathrm{~kg}^{-1}$ soil for the fertilizers; and $0.5,1,1.5,2$ and $2.5 \mathrm{~g} \mathrm{~kg}^{-1}$ soil for the nematicide (Cadusafos).

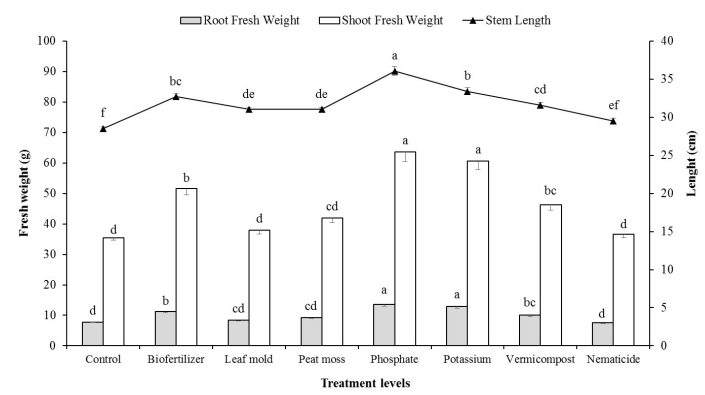

Figure 9. Effect of soil amendments on growth properties (fresh weight of root and shoot, and length of stem) of tomato seedlings in the free-nematode treatments.

fertilizers, RF was close to zero especially at phosphate dose of $16 \mathrm{~g} \mathrm{~kg}^{-1}$ soil (Figure 8).

The quantity of plant growth properties (root and shoot fresh weight, and stem length) increased as fertilizers dosage increased. The highest amount of the quantity was obtained in phosphate, vermicompost, biofertilizer, peat moss, potassium and leaf mold, respectively (Figure 9).

\section{Discussion}

The soil-inhabitant nematode population can be significantly suppressed by a wide range of amendments including biofertilizers, composts, crop residues, byproducts of plants, industrial or urban wastes, and green or animal manures, in the "in vitro" and "in vivo" assays (Hooks et al., 2010; Hu and Cao, 2008; Hu and Qi, 2010; McSorley, 2011; Mennan and Melakeberhan, 2010; Oka, 2010; Okada and Harada, 2007; Soheili and Saeedizadeh, 2017; Tranier et al., 2014; Zasada et al., 2010; Habash and Al-Banna, 2011).

In the current study, the fertilizers increased the mortality of $\mathrm{J}_{2} \mathrm{~s}$ and decreased egg hatching in Petri dish assays. According to the assays, the highest and lowest levels of suppressive effect on the nematode were observed in phosphate, biofertilizer, vermicompost, potassium, peat moss, and leaf mold treatments, respectively. It seems that chemical synthetic fertilizers have had a greater fatality effects on $\mathrm{J}_{2} \mathrm{~s}$ and eggs due to the type of ingredients and the major changes in the acidity of the reaction medium. Habash and Al-Banna (2011) found that the fertilizers containing calcium phosphonate, magnesium phosphonate, potassium phosphonate increased the mortality of $\mathrm{J}_{2} \mathrm{~s}$ and decreased the egg hatching of $M$. javanica and $M$. incognita in the "in vivo" assays. Also, potassium phosphonate (0.5\%) had no negative effects on $\mathrm{J}_{2} \mathrm{~s}$ egg hatching or survival. In the current study, the results of the "in vivo" assays showed that phosphate was as effective as Cadusafos in egg hatching inhibition and causing $100 \% \mathrm{~J}_{2}$ mortality at dose of $16 \mathrm{~g} \mathrm{l}^{-1}$ distilled water. These conditions were not observed in organic fertilizers such as peat moss, and leaf mold.

The results obtained in the Petri dish assays were confirmed by pot assay results. In pot assay, the most suppressive effect was observed in phosphate, biofertilizer, potassium, vermicompost, peat moss and leaf mold, respectively. In accordance with the results of the present study, Ismail and Hasabo (2000) studied on commercial Egyptian biofertilizers containing a variety of bacteria, fungi, and blue-green algae. They observed suppressive effects of the fertilizers on $M$. incognita, as well as improvement of the host plant in a greenhouse. These products significantly decreased the invasion of $\mathrm{J}_{2} \mathrm{~S}$ in the rhizosphere and in the nematode's reproduction in roots $(\mathrm{P} \leq 0.05)$. Also, El-Hadad et al. (2011) found positive results regarding the suppression capability of several biofertilizers containing phosphate-solubilizing bacteria, nitrogen-fixing bacteria, and potassium-solubilizing bacteria on rhizosphere-infested $M$. incognita in greenhouse conditions. To support such finding, the pot experiment conducted in the current study indicated that reproduction of the nematode significantly reduced, in terms of egg masses and $\mathrm{RF}(\mathrm{P} \leq 0.05)$, when soil was amended using phosphate, biofertilizer, potassium, 
and vermicompost, respectively. Thus, it can be found that the application of fertilizers causes a reduction in nematode activity.

Based on the results obtained regarding the effect of the type of fertilizer on the reduction of $M$. javanica activity, it can be inferred that the highest level of nematicidal effect was obtained in the treatment of phosphate in Petri dish experiments. The reduction of infectious population followed by a drop in galling in case of using phosphate, biofertilizer, and potassium treatments, indicating that these fertilizers have an acceptable nematicidal effect. This finding is similar to the results of the study by Zhao et al. (2016) who found that $M$. incognita infection on tomato seedlings reduced as a result of using potassium. For the plant host, by increasing $\mathrm{K}$ concentration up to $8 \mathrm{mM}$, enzyme activity (associated with resistance, and total phenol and flavonoid contents) was gradually enhanced. It should be noted that a higher $\mathrm{K}$ concentration $(16 \mathrm{mM})$ showed opposite effects. However, this is not consistent with the findings of the study by Smithson et al. (2001) who indicated that using phosphate did not have any effect on damage caused by nematodes on banana, although it gave a positive yield. Moreover, Olowe (2012) found that all phosphate treatments led to minor galled roots (49-63\%) compared to the control $(82 \%)$, and also the highest and least amount of gall was found in potassium $(70 \%)$ and nitrogen (49\%) treatments, respectively. Significantly $(\mathrm{P} \leq 0.05)$, low egg mass in phosphate treatment, compared to other fertilizers and the negative control can be associated with increased root growth, resulting in decreased galling and increased plant growth. Seemingly, the application of fertilizers in soil can offer solutions for the management of PPNs. It may be attributed to the amendments containing phosphate which induce a process of resistance in host plants against RKNs (Sharaf et al., 2016).

Fertilizers could also promote host tolerance to pathogens (Vejan et al., 2016) and cause mortality of nematodes (Ketabchi et al., 2016). Phosphorus is known to scrimp $\mathrm{pH}$ in soil; this may have a negative effect on infection and reproduction of nematodes (Ahmadi Mansourabad et al., 2016). Crop residues and some organic fertilizers are able to diffuse nitrogenous organic materials or organic acids, which could have harmful properties on phytopathogenic nematodes (Oka, 2010; Thoden et al., 2011). Hence, these findings may justify the relationship between repressive substances of nematodes and the reduction of soil $\mathrm{pH}$. It seems that changes in the behavior and reproduction of nematodes can lead to the changes in their populations; this phenomenon is considered as one of the direct effects of fertilizers. The ecological responses of the inhabitant-soil nematode population to adding fertilizer to soil depend on various agents, including ingredients of fertilizers. Soil amendments are capable to modify numerous parameters, directly attributed to the nematodes including soil physical properties (structure and particle aggregation) and soil chemical characteristics (acidity, salinity, and amounts of $\mathrm{CO}_{2}, \mathrm{O}_{2}$, and other materials) (Oka, 2010). A survey demonstrated that organic fertilizers could excite a wide domain of microorganisms in the food network, including abundant predator and parasite nematodes (Oka, 2010). Diversity in soil organic matter can directly influence the interactions of soil microbial populations including nematodes and their antagonists; and this finding is in line with those of other researchers (Thoden et al., 2011). In the experiment carried out in this study, due to the sterility of the tested soil, it can be suggested that organic soil amendments like vermicompost, peat moss, and leaf mold may cause chemical changes in the soil to the detriment of $M$. javanica populations, supported by the results of the study by Pathma and Sakthivel (2012), in which they found that adding vermicompost to the rhizosphere of strawberry, tomato, pepper, and grape caused a significant decrease in herbivore nematodes populations, as well as an amplification of fungivore and bacterivore nematodes compared to the soil treated with synthetic fertilizer (Pathma and Sakthivel, 2012).

In the present study, due to the effect of fertilizers on $\mathrm{J}_{2} \mathrm{~s}$ mortality and egg hatching of $M$. javanica, nematode-associated damage may be limited to the first period of growth after the application of fertilizers in the rhizosphere. It is believed that farmers need to wait for the positive effect of fertilizers on the suppression of the nematode population. It can be said that, although the effect of fertilizers (especially non-chemical fertilizers) is not as much as the nematicide in terms of nematode control, but despite of nematicides, the use of fertilizers (especially organic fertilizers) will not lead to many environmental concerns. More research is needed for better understanding regarding the soil amendment, and its effect on pathogenicity and reproduction of PPNs. However, due to the positive effect of organic fertilizers on growth parameters of plants, and also on stimulation of the food network in favor of saprophytic soil-inhabitant microbes, the use of soil amendment along with the fertilizers is recommended to control RKNs.

As a conclusion, soil fertilization led to a mild suppressive effect on galling and reproduction of M.javanica. Treatments of phosphate, biofertilizer, and potassium repressed the nematode population in soil and roots. The results of the current study suggested that replacing chemical nematicides with fertilizers may be considered as an acceptable strategy to achieve sustainable agriculture.

\section{Acknowledgements}

This work was supported by Shahed University, Tehran, Iran. We thank Mr. Kayvan Agahi for help with the statistical analysis.

\section{References}

AHMADI MANSOURABAD, M., KARGAR BIDEH, A. and ABDOLLAHI, M., 2016. Effects of some micronutrients and macronutrients on the root-knot nematode, Meloidogyne incognita, in greenhouse cucumber (Cucumis sativus cv. Negin). 
Journal of Crop Protection, vol. 5, no. 4, pp. 507-517. http:// dx.doi.org/10.18869/modares.jcp.5.4.507.

AL-BANNA, L., ALBESS, M.S., AL-WAHWAH, A.A. and GHANEM, A., 2007. Antimicrobial activity of locally manufactured fertilizers. In: Proceedings of the 6th Jordanian Agricultural Scientific Conference, 2007, Amman, Jordan. Jordan: University of Jordan, pp. 47.

BADO, V., SAWADOGO, A., THIO, B., BATIONO, A., TRAORÉ, K. and CESCAS, M., 2011. Nematode infestation and $\mathrm{N}$-effect of legumes on soil and crop yields in legume-sorghum rotations. Agricultural Sciences, vol. 2, no. 2, pp. 49-55. http:// dx.doi.org/10.4236/as.2011.22008.

CETINTAS, R. and CAKMAK, B., 2016. Meloidogyne species infesting tomatoes, cucumbers and eggplants grown in Kahramanmaraş Province, Turkey. Turkiye Entomoloji Dergisi, vol. 40, no. 4, pp. 355-364. http://dx.doi.org/10.16970/ted.40839.

COOLEN, W.A. and D'HERDE, C.J., 1972. A method for the quantitative extraction of nematodes from plant tissue. Ghent: State Agricultural Research Centre. 77 p.

EDWARDS, C.A., ARANCON, N.Q., EMERSON, E. and PULLIAM, R., 2007. Suppressing plant parasitic nematodes and arthropod pests with vermicompost teas. BioCycle, vol. 48, no. 12 , pp. $38-39$.

EL-HADAD, M.E., MUSTAFA, M.I., SELIM, SM., EL-TAYEB, T.S., MAHGOOB, A.E. and ABDEL AZIZ, N.H., 2011. The nematicidal effect of some bacterial biofertilizers on Meloidogyne incognita in sandy soil. Brazilian Journal of Microbiology, vol. 42, no. 1, pp. 105-113. http://dx.doi.org/10.1590/S151783822011000100014. PMid:24031611.

GHARABADIYAN, F., JAMALI, S. and KOMEILI, R.H., 2013. Determining of root-knot nematode (Meloidogyne javanica) damage function for tomato cultivars. Journal of Agricultural Sciences, vol. 58, no. 2, pp. 147-157. http://dx.doi.org/10.2298/ JAS1302147G.

GOWEN, S.R., 1997. Chemical control of nematodes: efficiency and side-effects. FAO Plant Production and Protection Paper, vol. 144, pp. 59-65.

HABASH, S. and AL-BANNA, L., 2011. Phosphonate fertilizers suppressed root knot nematodes Meloidogyne javanica and M. incognita. Journal of Nematology, vol. 43, no. 2, pp. 95-100. PMid:22791918.

HOOKS, C.R., WANG, K.-H., PLOEG, A. and MCSORLEY, R., 2010. Using marigold (Tagetes spp.) as a cover crop to protect crops from plant-parasitic nematodes. Applied Soil Ecology, vol. 46, no. 3, pp. 307-320. http://dx.doi.org/10.1016/j.apsoil.2010.09.005.

HU, C. and CAO, Z.-P., 2008. Nematode community structure under compost and chemical fertilizer management practice, in the north China plain. Experimental Agriculture, vol. 44, no. 4, pp. 485-496. http://dx.doi.org/10.1017/S0014479708006716.

HU, C. and QI, Y., 2010. Effect of compost and chemical fertilizer on soil nematode community in a Chinese maize field. European Journal of Soil Biology, vol. 46, no. 3-4, pp. 230-236. http:// dx.doi.org/10.1016/j.ejsobi.2010.04.002.

HUSSEY, R. and BARKER, K.R., 1973. A comparison of methods of collecting inocula of Meloidogyne spp., including a new technique. The Plant Disease Reporter, vol. 57, pp. 1025-1028.

HUSSEY, R.S. and JANSSEN, G.J.W., 2002. Root-knot nematodes: Meloidogyne species. In: J.L. STARR, R. COOK and J. BRIDGE, eds. Plant resistance to parasitic nematodes. Wallingford: CAB Publishing. http://dx.doi.org/10.1079/9780851994666.0043.

ISMAIL, A. and HASABO, S., 2000. Evaluation of some new Egyptian commercial biofertilizers, plant nutrients and a biocide against Meloidogyne incognita root knot nematode infecting sunflower. Pakistan Journal of Nematology, vol. 18, no. 1-2, pp. 39-49.

JENKINS, W.R., 1964. A rapid centrifugal-flotation technique for separating nematodes from soil. The Plant Disease Reporter, vol. 48 , no. 9 , pp. 692 .

KETABCHI, S., CHAREHGANI, H. and MAJZOOB, S., 2016. Impact of rhizosphere antagonistic bacteria and urea fertilizer on root knot nematode (Meloidogyne Incognita) under green house condition. Journal of Animal and Plant Sciences, vol. 26, no. 6, pp. $1780-1786$.

KHAN, Z., TIYAGI, S.A., MAHMOOD, I. and RIZVI, R., 2012. Effects of $\mathrm{N}$ fertilisation, organic matter, and biofertilisers on the growth and yield of chilli in relation to management of plant-parasitic nematodes. Turkish Journal of Botany, vol. 36, no. 1, pp. $73-81$.

MALEITA, C.M., CURTIS, R.H., POWERS, S.J. and ABRANTES, I.M.O., 2012. Inoculum levels of Meloidogyne hispanica and M. javanica affect nematode reproduction, and growth of tomato genotypes. Phytopathologia Mediterranea, vol. 51, no. 3, pp. 566-576. http://dx.doi.org/10.14601/Phytopathol_Mediterr-9740.

MCSORLEY, R., 2011. Overview of organic amendments for management of plant-parasitic nematodes, with case studies from Florida. Journal of Nematology, vol. 43, no. 2, pp. 69-81. PMid:22791915.

MELO SANTANA-GOMES, S., DIAS-ARIEIRA, C.R., ROLDI, M., SANTO DADAZIO, T., MARINI, P.M. and DE OLIVEIRA BARIZATILDE, D.A., 2013. Mineral nutrition in the control of nematodes. African Journal of Agricultural Research, vol. 8, no. 21, pp. 2413-2420. http://dx.doi.org/10.5897/AJARx12.008.

MENNAN, S. and MELAKEBERHAN, H., 2010. Effects of biosolid amendment on populations of Meloidogyne hapla and soils with different textures and pHs. Bioresource Technology, vol. 101, no. 18, pp. 7158-7164. http://dx.doi.org/10.1016/j. biortech.2010.04.023. PMid:20427181.

OKA, Y., 2010. Mechanisms of nematode suppression by organic soil amendments-a review. Applied Soil Ecology, vol. 44, no. 2, pp. 101-115. http://dx.doi.org/10.1016/j.apsoil.2009.11.003.

OKADA, H. and HARADA, H., 2007. Effects of tillage and fertilizer on nematode communities in a Japanese soybean field. Applied Soil Ecology, vol. 35, no. 3, pp. 582-598. http://dx.doi. org/10.1016/j.apsoil.2006.09.008.

OLOWE, T.O., 2012. The effect of fertilizer (NPK) on infestation of Meloidogyne incognita on cowpea, Vigna unguiculata (L.). British Journal of Science, vol. 6, no. 2, pp. 25-42.

PADGHAM, J. and SIKORA, R., 2007. Biological control potential and modes of action of Bacillus megaterium against Meloidogyne graminicola on rice. Crop Protection, vol. 26, no. 7, pp. 971-977. http://dx.doi.org/10.1016/j.cropro.2006.09.004.

PATHMA, J. and SAKTHIVEL, N., 2012. Microbial diversity of vermicompost bacteria that exhibit useful agricultural traits and waste management potential. SpringerPlus, vol. 1, no. 1, pp. 26. http://dx.doi.org/10.1186/2193-1801-1-26. PMid:23961356. 
PERRY, R.N., MOENS, M. and STARR, F.J., 2009. Rootknot nematodes. Wallingford: CAB International. http://dx.doi. org/10.1079/9781845934927.0000.

PLOEG, A., 2008. Biofumigation to manage plant-parasitic nematodes. In: A. CIANCIO and K.G. MUKERJI, eds. Integrated management and biocontrol of vegetable and grain crops nematodes. Dordrecht: Springer, pp. 239-248. http://dx.doi. org/10.1007/978-1-4020-6063-2_12.

SAEEDIZADEH, A., 2016. Trichoderma viride and Pseudomonas fluorescens CHA0 against Meloidogyne javanica in the rhizosphere of tomato plants. Hellenic Plant Protection Journal, vol. 9, no. 1, pp. 28-34. http://dx.doi.org/10.1515/hppj-2016-0003.

SAFDAR, H., JAVED, N., KHAN, S.A., UL HAQ, I., SAFDAR, A. and KHAN, N., 2012. Control of Meloidogyne incognita (Kofoid and White) chitwood by cadusafos (Rugby ${ }^{\circledR}$ ) on tomato. Pakistan Journal of Zoology, vol. 44, no. 6, pp. 1703-1710.

SHARAF, A.E.-M.M., KAILLA, A.M., ATTIA, M.S. and NOFAL, M.M., 2016. Induced resistance in tomato plants against root knot nematode using biotic and abiotic inducers. International Journal of Advanced Research in Biological Sciences, vol. 3, no. 11, pp. 31-46. http://dx.doi.org/10.22192/ijarbs.2016.03.11.004.

SMITHSON, P.C., MCINTYRE, B.D., GOLD, C.S., SSALI, H. and KASHAIJA, I.N., 2001. Nitrogen and potassium fertilizer vs. nematode and weevil effects on yield and foliar nutrient status of banana in Uganda. Nutrient Cycling in Agroecosystems, vol. 59, no. 3, pp. 239-250. http://dx.doi.org/10.1023/A:1014462923539.

SOHEILI, A. and SAEEDIZADEH, A., 2017. Suppression of brassicaceous tissue on Meloidogyne javanica in a rhizosphere. International Journal of Agriculture and Biology, vol. 19, no. 5, pp. 1012-1018. http://dx.doi.org/10.17957/IJAB/15.0400.

SULTANA, V., BALOCH, G.N., ARA, J., TARIQ, M. and EHTESHAMUL-HAQUE, S., 2011. Comparative efficacy of a red alga Solieria robusta, chemical fertilizers and pesticides in managing the root diseases and growth of soybean. Pakistan Journal of Botany, vol. 43, no. 1, pp. 1-6.

TABATABAEI, F.S. and SAEEDIZADEH, A., 2017. Rhizobacteria cooperative effect against Meloidogyne javanica in rhizosphere of legume seedlings. Hellenic Plant Protection Journal, vol. 10, no. 1, pp. 25-34. http://dx.doi.org/10.1515/ hppj-2017-0003.

THODEN, T.C., KORTHALS, G.W. and TERMORSHUIZEN, A.J., 2011. Organic amendments and their influences on plantparasitic and free-living nematodes: a promising method for nematode management? Nematology, vol. 13, no. 2, pp. 133-153. http://dx.doi.org/10.1163/138855410X541834.

TRANIER, M.-S., POGNANT-GROS, J., QUIROZ, R.D.L.C., GONZÁLEZ, C.N.A., MATEILLE, T. and ROUSSOS, S., 2014. Commercial biological control agents targeted against plantparasitic root-knot nematodes. Brazilian Archives of Biology and Technology, vol. 57, no. 6, pp. 831-841. http://dx.doi.org/10.1590/ S1516-8913201402540.

VEJAN, P., ABDULLAH, R., KHADIRAN, T., ISMAIL, S. and NASRULHAQ BOYCE, A., 2016. Role of plant growth promoting rhizobacteria in agricultural sustainability-a review. Molecules, vol. 21, no. 5, pp. 573. http://dx.doi.org/10.3390/ molecules21050573. PMid:27136521.

ZASADA, I.A., HALBRENDT, J.M., KOKALIS-BURELLE, N., LAMONDIA, J., MCKENRY, M.V. and NOLING, J.W., 2010. Managing nematodes without methyl bromide. Annual Review of Phytopathology, vol. 48, no. 1, pp. 311-328. http://dx.doi. org/10.1146/annurev-phyto-073009-114425. PMid:20455696.

ZHAO, X., HU, W., ZHANG, S., ZHAO, Q. and WANG, Q., 2016. Effect of potassium levels on suppressing root-knot nematode (Meloidogyne incognita) and resistance enzymes and compounds activities for tomato (Solanum lycopersicum L.). Academia Journal of Agricultural Research, vol. 4, no. 5, pp. 306-314. 